\title{
METODOLOGIE TVORBY NÁRODNÍHO REKLAMNÍHO STYLU
}

\section{Eva Kazíková}

\section{Klíčová slova:}

kultura, kulturní dimenze dle Hofstedeho, kulturní dimenze dle Schwartze, komunikační kontext, národní reklamní styl, explorační analýza

\section{Keywords:}

culture, Hofstede's cultural dimensions, Schwartz's cultural dimensions, communication context, national advertising style, exploratory analysis

\begin{abstract}
Abstrakt
Tento text představuje metodologický postup pro tvorbu národních reklamních stylů, který je důležitý pro cílování reklamních kampaní v jiných než domácích regionech. Metodologický postup vychází z řady výzkumů, které byly již realizovány a publikovány. První fáze je zaměřena na určení kulturních dimenzí dle profesora Hofstedeho a Schwartze. Následně je třeba určit komunikační kontext daného regionu a aplikovat do něj nejvýraznější kulturní dimenze. Na základě těchto postupů vytvoříme konkrétní národní reklamní styly.
\end{abstract}

\begin{abstract}
This text shows a methodological approach for creating national advertising style which is very important for aiming advertising campaigns in non-domestic regions. This approach is based on a numbers of many researches which have been realized and published. First phase is focuses on identifying of cultural dimensions by professor Hofstede and Schwartze. After that is necessary to identify communication context of advertisements in specific region and apply in it the most significant cultural dimensions. We can create specific national advertising style based on these principals.
\end{abstract}

\section{Úvod}

Kultura (potažmo společnost) je souborem hmotných a nehmotných prvků, které slouží k orientaci člověka ve společnosti, a mají vliv na obecné chování člověka, stejně tak i na nákupní a spotřební chování. Do hmotných prvků kultury (společnosti) můžeme zařadit materiální lidské výtvory (artefakty) - tj. „typické“ zboží, obaly, odpad a nakládání s nimi. Do nehmotných prvků kultury řadíme Sociokulturní regulativy (zákony, normy, hodnoty, pravidla, tabu, omezení, apod.), dále to jsou Ideje a symbolické systémy (jazyk, písmo, náboženství, mýty, umění - hudba, architektura, literatura, tanec, apod.) a v neposlední řadě do těchto prvků řadíme Instituce organizujicí lidské chování (rodina, manželství, rodinné vztahy, církve, spolky, apod.).

Pro lepší pochopení této problematiky je nutné si také uvědomit, jaké rysy může kultura mít: (Zemanová, M. a kol., 2010)

Kultura je určená - kulturu si spotřebitelé v průběhu své tzv. socializace osvojují. Podstatnou roli při tom sehrávají různé kulturní zdroje, mezi které patří národní prostředí, jazyk, náboženství, rodinné zázemí, profesní prostředí a další.

Kultura se přenáší z generace na generaci - hlavním výrazem tohoto kulturního rysu, který zajišt'uje kulturní kontinuitu, je tradice. Určité produkty, značky jsou tradiční, v dané kultuře zaujímají relativně trvalý a zřetelný výkladový prostor, danou kulturu i vyjadřují. 
Kultura sdílená - převedeno do marketingového významu: velká skupina spotřebitelů sdílí, má podobné spotřební projevy, podobnou spotřební kulturu.

Kultury jsou diferencované - současně existují různé kultury, různá kulturní prostředí. Jejich členové se ve svých kulturních projevech navzájem zřetelně odlišují. Tyto diference pak mohou vést k nutnosti volit vůči každé kultuře odlišný marketingový prŕístup (mix).

Kultura je adaptivní - kultury se v čase mění. Přestože kulturní prostředí představuje poměrně stabilní rámec lidského (a spotřebního) chování, i ono prochází změnami, které mají sice většinou relativně pozvolný charakter, ale vzhledem $\mathrm{k}$ jejich propojení s předchozími polohami mohou znamenat výraznou podmínku pro orientaci marketingu.

Výše zmíněné pojmy spolu tedy velice úzce souvisí. Tyto pojmy jsou v dnešní době velice diskutovaným tématem. Existují kritičtí odpůrci globalizace, ale také zcela nekritičtí př́ijemci. Globalizace sebou jistě přináší řadu možností a otevřených dveří, ale jako vše má i své stinné stránky a problémy, které je nutno řešit, abychom dosáhli rovnováhy. Z řady studií a výzkumů je možné získat základní data, se kterými je nutné dále pracovat.

Globalizace je z hlediska ekonomických subjektů obousměrný proces. Lokální podniky se orientují na světové trhy a světové výrobky pronikají na trhy lokální. Pro lokální podniky to většinou znamená restrukturalizaci a adaptaci na globální světové parametry za využití metod a nástrojů mezinárodního marketingu. Země střední a východní Evropy včetně České republiky se staly oblastí pro umist'ování zahraničních investic, které znamenají v řadě oblastí silnou konkurenci. Řešením není uzavření místního trhu, ale schopnost mezinárodní konfrontace, která přináší impulzy pro inovaci a vede ke konkurenceschopnosti na globální úrovni. (Vysekalová, J. a kol., 2011)

\section{Cíl článku, resp. disertační práce}

Cílem tohoto článku je vytvořit ucelenou metodologii pro získání definice národního reklamního stylu. Tuto metodologii jsem se rozhodla vytvořit $\mathrm{z}$ toho důvodu, že je potřebná pro mou disertační práci, která je zaměřená na téma Interkulturní rozdíly v marketingové komunikaci. Cílem mé disertační práce je tedy analýza a srovnání kulturních dimenzí sousedních zemí České republiky - Německa, Rakouska, Polska, Slovenska. Dále tyto dimenze aplikovat na jednu z oblastí marketingového komunikačního mixu (obsahu a provedení reklamního sdělení) jednotlivých zemí a zdůraznit konkrétní specifika jednotlivých kultur a možnosti jejich využití pro úspěšnou a efektivní marketingovou komunikaci.

Pro zkoumání dané problematiky jsem si určila několik dílčích cílů, od kterých se odvíjí celá struktura celé metodologie:

- Studium a srovnání kulturních dimenzí jednotlivých zemí.

- Určení vlivu nejvýraznějších dimenzí na danou kulturu.

- Určení komunikačního kontextu jednotlivých zemí. (Jak se projevuje existence kulturních dimenzí na konkrétních příkladech reklam na produkty nabízené v dané zemi.)

- Srovnání komunikačního kontextu jednotlivých zemí.

- Využití nejvýraznějších závislostí v rámci komunikačního kontextu při určování a tvorbě reklamního stylu jednotlivých zemí. 
Pro objasnění dílčích cílů jsem využila obecné teoretické poznatky z odborné literatury a internetových zdrojů odborníků na danou problematiku. Jedná se především o zahraniční zdroje, vzhledem k tomu, že je tato problematika v zahraničí zkoumána ve větší míre než v České republice a díky tomu jsou relevantní data dostupnější. Dále byla použita statistická data z publikovaných studií a výzkumů, která jsou za tímto účelem získávána již řadu let naprríč celým světem. Na těchto výzkumech se podílí celá řada odborníků s celého světa a tyto výzkumy jsou sestavovány na základě přísných metodologií, které byly vytvořeny z poznatků nejznámějších a nejuznávanějších vědeckých pracovníků v oboru. Pravidelně jsou prováděna opakovaná průřezová šetření, aby bylo dosaženo aktualizací konkrétních statistických dat. Tato opakovaná šetření mohou probíhat hlavně díky finanční podpoře řady evropských a světových institucí.

Hlavní přínos tvorby této metodologie spatřuji v definování národních reklamních stylů jednotlivých zemí, které je možné využít pro hlubší analýzy a komparace dalším zájemcům o tuto problematiku. Výstup tohoto textu, resp. disertační práce může být nástrojem pro rozhodování marketingových manažerů o vhodnosti použití konkrétní reklamní kampaně a v neposlední řadě ho lze využít také pro další vědecká zkoumání.

\section{Metodologie}

\subsection{Kulturní dimenze dle G. Hofstedeho}

Pro zpracování své disertační práce jsem použila metodologii a výsledky výzkumů Gerta Hofstedeho a jeho kolegů. Jedná se o analýzu národních kultur podle důležitosti a významu kulturních hodnot a nalezení kritérií, podle nichž by bylo možno objektivně a srozumitelně popsat interkulturní rozdíly. Kulturní dimenze postihují chování člověka každé společnosti a lze je shrnout do těchto základních skupin: (Světlík, J., 2003)

1. vztah $k$ autoritám,

2. koncepce vlastního já, především:

a) vztah mezi jednotlivcem a kolektivem,

b) individuální koncepce mužských a ženských hodnot,

3. způsob řě̌ení konfliktů, včetně kontroly agrese a vyjádření pocitů.

Na základě této klasifikace byly definovány dimenze jednotlivých kultur. Hofstede definuje kulturní dimenze následovně: „Dimenze je projevem kultury, který může být měřen ve vztahu ke kulturám jiným.“ Pro objektivnější srovnání různých národních kultur je nutné definovat tyto dimenze a nalézt způsob jejich měřní.

Geert Hofstede na základě svého výzkumu zjistil, že je možné rozlišit tyto následující čtyři kulturní dimenze:

Rozpětí moci v hierarchii. Na této dimenzi je možné ukázat, do jaké míry jsou v určité kultuře akceptovány nerovné mocenské poměry.

Individualismus/kolektivismus. Na této dimenzi je možné ukázat, do jaké míry se členové určité kultury definují jako součást sociální pospolitosti a do jaké míry se cítí být jí zavázání.

Vyhýbání se nejistotě. Na této dimenzi je možné ukázat, do jaké míry nejasné a víceznačné situace vyvolávají v určité kultuře nejistotu a obavy. 
Maskulinita/feminita. Na této dimenzi je možné ukázat, do jaké míry jsou v určité kultuře od sebe oddělovány mužské a ženské role a do jaké míry jsou pevně stanovené.

Geert Hofstede tyto čtyři dimenze později doplnil na základě výsledů studie, kterou provedla skupina vědců v Číně, o následující pátou dimenzi:

Dlouhodobá orientace. Na této dimenzi je možné ukázat, do jaké míry je v určité kultuře oceňováno dlouhodobé myšlení.

Dle informací na stránkách profesora Hofstedeho byly tyto dimenze rozšířeny ještě o jednu šestou dimenzi:

Požitkářství/zdrženlivost. Požitkářství znamená pro společnost, která umožňuje relativně svobodné uspokojení základních a přirozených potřeb člověka, možnost bavit se a užívat si života. Zdrženlivost je naopak symbol pro společnost, která potlačuje uspokojování těchto potřeb a upravuje ji pomocí přísných společenských norem (Dimensions of national cultures [on-line], 2010).

\subsection{Kulturní dimenze dle S. Schwartze}

Ve své metodologii se také zaměřím na zjišt'ování kulturních hodnot dle Shaloma Schwartze (1994), který definoval celkem 7 typů hodnot na kulturní úrovni a současně i definoval jejich vzájemný vztah. Využitelnost Schwartzova výzkumu se nabízí především v oblasti tvorby reklamních apelů. Jedná se o tyto typy kulturních hodnot: (Schwartz, S.H., 1994)

Hierarchie. Důraz je kladen na legitimitu hierarchické alokace rolí a zdrojů (autorita, pokora, síla vlivu, sociální síla, atd.).

Konzervatismus. Klade důraz na zdvořilé chování a status quo.

Harmonie. Zdůrazňuje harmonický soulad s prostředím - ochrana prostředí, jednota s prírodou apod.

Rovnost. Zdůrazňována je přednost blaha a prospěchu pro jiné před egoistickými zájmy jednotlivce (rovnost, svoboda, ochota pomoci, loajalita, odpovědnost, sociální spravedlnost, život v pokoji a míru).

Intelektuální a emocionální autonomie. Důraz je kladen na podporu a ochranu nezávislého myšlení a názorů a také na prosazování práva vlastního intelektuálního směřování jednotlivce (kreativita, zvídavost a tolerance). V případě emocionální autonomie na podporu a ochranu prosazování práva jednotlivce na emociální prožívání pozitivní zkušenosti (hédonismus, užívání si života, vzrušující život, apod.).

Výkon/úspěch. Důraz je kladen na úspěch prostřednictvím aktivního sebeuplatnění, přeměnou a ovládnutím přírodního a sociálního prostředí - úspěch, ambice, nezávislost, odvaha, smělost, schopnosti, volba vlastních cílů.

\section{Komunikační kontext}

K popisu a pochopení problematiky komunikačního kontextu pro účely tohoto textu, resp. mé disertační práce jsem použila definic a rozdělení pana Mikuláštíka (Mikuláštík, M., 2003). Komunikační kontext je situace, celkový rámec, ve kterém komunikace probíhá. Má svoji složku vnitřní a vnější. Vnitřní je to, co se odehrává v nás, v naslouchajících, jak na nás komuniké působí (nejsme tabula rasa, jsme určitým způsobem nastaveni, naše zkušenosti nás 
určitým způsobem připravují). Vnějším kontextem jsou všechny stimuly, které na nás působily dříve a působí i nyní (prostor, kde se nacházíme, čas, lidé a jejich chování...). Kontext je záležitostí nejen psychologickou a sociální, ale i kulturní. Například egocentrismus - vnímání vlastní kultury jako nejvyspělejší a nejdůležitější, individualismus západní Evropy a Spojených států. Nebo kolektivismus v kultuře Afriky - v tomto pojetí je individualismus chápán jako nezodpovědnost a nekulturnost. Kolektivismus Japonska a jiných zemí Dálného východu - od nejútlejšího dětství jsou lidé v tomto kulturním okruhu vedeni k tomu, aby si uvědomovali vliv svých činů na druhé, pocity odpovědnosti za jiné, pocity viny, když v tomto smyslu neobstojí. Kontext politický v tzv. socialistickém táboře, kde je násilně preferováno rovnostářství, obět' pro kolektiv, orientace na budoucnost, naprostá poslušnost.

To, co na nás v kontextu působí, co ovlivňuje komunikaci, se označuje jako kontextová modalita, tj. jednotlivé stimulační vlivy:

- čas (kdy komunikace probíhá a časový prostor, který je pro komunikaci $\mathrm{k}$ dispozici);

- hmotný prostor, v němž komunikace probíhá;

- emoční vybavení;

- mezilidské vztahy, míra formálnosti;

- míra shody v jazyku dorozumívání a způsob vzájemného chápání a interpretace obou stran;

- stereotypy a očekávání chování vymezeného rolemi;

- záměry a motivace účastníků;

- sociální situace;

- věk účastníků komunikace, pohlaví;

- pozice účastníků komunikace z hlediska moci, kvalifikace, společenské role (když vám řekne policista „pojd’te se mnou“, je to vnímáno jinak, než když vám to řekne kněžka lásky nebo průvodce v muzeu).

Ačkoli nemůžeme do všech zákoutí výše uvedených vlivů stoprocentně proniknout, můžeme alespoň co nejblíže specifikovat cílovou skupinu zákazníků a vytvořit tak velice efektivní marketingovou strategii.

\section{Národní reklamní styl}

Národní reklamní styl je vhodně zvolená kombinace prvků z několika oblastí reklamy, které jsou nejvíce kulturně ovlivněny. Jedná se především o volbu stylu komunikace, hodnoty a motivace obsažené v reklamním apelu, formát reklamy a její provedení (prostředí, počet osob a jejich pohlaví, situace a činnosti, v nichž jsou zachyceni, výprava, hudba apod.).

Národní reklamní styl by měl dodržovat nejdůležitější zásady při tvorbě reklamy na mezinárodních trzích: (Světlík, J., 2005)

- co je úspěšné na domácím trhu, nemusí být plně funkční v zahraničí,

- reklamní sdělení musí mít pro cílovou skupinu smysl a význam,

- sdělení musí apelovat na nějaký citlivý bod vyvolávající u cílové skupiny přání nebo určitou touhu,

- sdělení nesmí cílovou skupinu nějakým způsobem urážet,

- musí respektovat místní pravidla a předpisy,

- při vytvoření globálního motivu reklamy je často potřeba tento motiv „lokalizovat“ na podmínky místní kultury, 
- minimalizovat nebezpečí vyplývající z nesprávného překladu textu,

- při stanovení reklamních cílů přihlížet k podmínkám místních trhů a kulturním rozdílům,

- jasně vymezit cílovou skupinu reklamního sdělení,

- vyhodnotit vlastnosti a zvolit pro kampaň nejvhodnější místní média,

- vyhodnotit a využít místní reklamní agentury.

Při zpracování jakéhokoli výzkumu na toto téma je nutné tyto zásady dodržovat a především se detailněji zaměřit na definování jednotlivých oblastí národního reklamního stylu každé země.

\section{Explorační analýza}

Po sběru všech dostupných dat je nutné tato data zpracovat a relevantním způsobem vyhodnotit. Jako vhodný typ hodnocení poslouží explorační analýza, která představuje souhrn metod používaných pro průzkum dat a hledání hypotéz, které stojí za to testovat. Jedná se v podstatě o metody zjišstování a verifikace různých druhů souvislostí a závislostí mezi vstupními veličinami nebo jejich kombinacemi.

Za hlavní úkoly explorační analýzy dat je možné považovat tyto:

- Navrhnout hypotézy o př́činách pozorovaných jevů

- Ověřit předpoklady zvolených statistických metod

- Podložit výběr vhodných statistických technik a nástrojů

- Poskytnout základnu dalšímu sběru dat pomocí průzkumů či experimentů

Vhodné metody pro zapojení do explorační analýzy při tvorbě národního reklamního stylu: pátrání v datech, kvantilová analýza, grafy, tabelace, korelační analýza, faktorová analýza, shluková (seskupovací) analýza atd.

\subsection{Kvantilová analýza}

Kvantilová analýza v sobě zahrnuje:

Vlastnosti statistické řady - poloha, rozptýlení, symetrie, kombinaci dvou nebo několika homogenních souborů, cizí pozorování nepatřící do souboru.

Charakteristiky uspořádání statistické řady - rozpětí, minimum a maximum, medián - neboli prostřední člen řady, respektive průměr mezi dvěma prostředními hodnotami, kvartily oddělují čtvrtinu nejnižších a nejvyšších čísel statistické řady, hradby - oddělují pozorování, která patří k souboru jen s nepatrnou pravděpodobností, přilehlá pozorování - přiléhají ke vnitřku hradby, ale nepřekročí ji, nevynecháváme je ze souboru, kvantily - oddělují určité zvolené procento počtu pozorování, kvantilové rozpětí - rozdíl mezi prvním a posledním kvantilem.

V př́ípadě kvantilové analýzy se také setkáváme s pojmem krabicový diagram neboli box plot, který nám umožňuje posoudit symetrii a variabilitu námi zvolených a dat a existenci extrémních hodnot.

Na základě této analýzy si uděláte základní obraz o statistickém souboru, se kterým chcete pracovat, a na základě získaných dat je možné využít další uváděné analýzy. 


\subsection{Korelační analýza}

Korelační analýza je metodou poměrně širokého statistického zkoumání existence potenciální závislosti mezi dvěma náhodnými proměnnými nebo mezi dvěma soubory dat, z nich ani jeden není pod kontrolou pořizovatele údajů. Její úvahy jsou založeny na tom, že závislost je opakem nezávislosti, tedy že mezi údaji, které nevykazují statistickou nezávislost, by př́činná závislost mohla existovat.

Tato úvaha se může na první pohled zdát poněkud nepřehledná. Zjednodušeně řečeno, vidíme-li ve zkoumaných souborech dat korelační tendence, pak to ještě neznamená, že zde existuje skutečná prŕícinná závislost. Příkladem může být statistická podobnost údajů o dobré náladě v souvislosti s dobrým zdravím. Není překvapivé, pokud nemocný člověk není dobře naložen, neplatí ale, že se jedinec ve skvělé náladě nemůže potýkat s chorobou. (Svozilová, A., 2011)

\subsection{Faktorová analýza}

Faktorová analýza je statistická metoda, která slouží k vysvětlení rozptylu pozorovaných proměnných pomocí menšího počtu latentních proměnných, tzv. faktorů. Smyslem této analýzy je především měřit něco, co není přímo měřitelné. Proto tato analýza našla široké uplatnění hlavně v psychologii, sociologii, marketingu a dalších podobných oborech.

Tato analýza se snaží každou pozorovanou proměnnou popsat jako kombinaci vlivů jednotlivých faktorů. Počet faktorů použitých v této analýze se může různit. Větší procento rozptylu proměnných je vysvětleno při větším výpočtu faktorů. Není to ale smyslem faktorové analýzy, ideální je nalézt pokud možno co nejmenší adekvátní počet faktorů. Počet volených faktorů je tedy nutné určovat na základě konkrétních dat.

\subsection{Shluková analýza (seskupovací analýza)}

Shluková analýza je metoda, která se zabývá vyšetřováním podobnosti vícerozměrných objektů a jejich klasifikací do tříd čili shluků. Tato analýza se hodí zejména tam, kde objekty vykazují prrirozenou snahu se seskupovat.

Shluková analýza je metoda, jejímž cílem je přiřadit jednotky analýzy (např. osoby, případy, události apod.) na základě podobnosti ke skupinám (shlukům, trsủm). Přitom charakteristiky shluků ani jejich počet nejsou předem známy - musí být odvozeny z výzkumných dat. Mírou podobnosti (resp. nepodobnosti) jednotek analýzy bývá často korelace. (Chráska, M., 2007)

Tuto analýzu je možné provádět na množině objektů, kde každá množina objektů musí být popsána prostřednictvím stejného souboru znaků, které je účelné v dané množině zkoumat. Tato definice platí také naopak, analýzu lze provádět také na množině znaků, které jsou charakterizovány prostřednictvím souboru objektů (nositelů těchto znaků).

\section{Závěr}

V tomto článku jsem se snažila vytvořit postup metod zkoumání při tvorbě národního reklamního stylu. Zvolený postup vychází od prvotního sběru dat a informací, které bude možno dále zpracovávat a analyzovat. Zvolený metodologický postup vychází z požadavků na mou disertační práci. $\mathrm{V}$ textu je nastíněna problematika a postup teoretického získávání dat převážně ze sekundárních zdrojů, především z již zpracovaných odborných studií či projektů. 
V dalších fázích by měla následovat fáze srovnávání a především fáze statistických analýz, abychom byli schopni ověrit a dokázat svá tvrzení.

Věřím, že tento článek bude přínosem pro všechny, kteří by chtěli více proniknout do této problematiky, která je celosvětově ožehavým tématem, a věnovat se další výzkumné činnosti.

\section{Literatura:}

[1] HOFSTEDE, G. J., HOFSTEDE, G., PEDERSEN, P. B. Exploring culture: exercises, stories, and synthetic cultures. Boston: Intercultural Press, Inc., a division of Nicholas Brealey Publishing, 2002. 234 s. ISBN-13: 978-1-877864-90-2, ISBN-10: 1-877864-900.

[2] HOFSTEDE, G., HOFSTEDE, G. J. Kultury a organizace. Software lidské mysli. Spolupráce mezi kulturami a jeji di̊ležitost pro přežití. Linde nakladatelství, 2007, 335 s. ISBN 80-86131-70-X.

[3] CHRÁSKA, M. Metody pedagogického výzkumu: Základy kvantitativního výzkumu. Grada Publishing, Praha, 2007, 265 s. ISBN 978-80-247-1369-4.

[4] SCHWARTZ, S.H. Beyond individualism/collectivism: New cultural dimensions of values. In U. Kim, H. C. Triandis, C. Kagitcibasi, S. C. Choi and G. Yoon (Eds.), Individualism and Collectivism: Theory, Method and Applications. (pp. 85-119). Thousand Oaks CA: Sage, 1994. ISBN 0-8-0395-763-7.

[5] SVĚTLÍK, J. A KOL. Kulturní aspekty české a evropské reklamy. První vydání, Vysoké učení technické v Brně, Fakulta podnikatelská, 2008, 56 s. ISBN 978-80-86946-92-4.

[6] SVĚTLÍK, J. Marketing pro evropský trh. První vydání, Grada Publishing, Praha, 2003. 272 s. ISBN 80-247-0422-6.

[7] SVĚTLÍK, J. Euromarketing. První vydání, Univerzita Tomáše Bati ve Zlíně, 2005, 158 s. ISBN 80-7318-144-4.

[8] SVOZILOVÁ, A. Zlepšování podnikových procesů. Grada Publishing, Praha, 2011, 232 s. ISBN 978-80-247-3938-0.

[9] VYSEKALOVÁ, J. A KOL. Chování zákazníka. Jak odkrýt tajemství „černé skřiňky“. Grada Publishing, 2011, 360 s. ISBN 978-80-247-3528-2

[10] ZEMANOVÁ, M. A KOL. Marketing. 2.přepracované a doplněné vydání, C.H.Beck, Praha, 2010, 499 s. ISBN 978-80-7400-115-4.

\section{Internetové zdroje:}

[1] Hofstede, G. Dimensions of national cultures [online]. Geert Hofstede [cit. 2011-0526]. Dostupné $\mathrm{z}<\mathrm{http}$ ///www.geerthofstede.nl/dimensions-of-national-cultures $>$.

JEL M31, M37, Z100, Z190

\section{Ing. Eva Kazíková}

studentka doktorského studia

Obchodně podnikatelská fakulta v Karviné

Slezská univerzita v Opavě

Univerzitní náměstí 1934/3, 73340 Karviná

eva.kazikova@probull.cz 